\title{
A HELYI ÉRTÉKEK IDENTITÁSERŐSÍTŐ ÉS KÖZÖSSÉGÉPÍTŐ SZEREPE A VAJDASÁGI TISZA MENTÉN
}

\author{
Kormányos Katona Gyöngyi \\ Nemzetstratégiai Kutatóintézet; e-mail: procultura.zenta@gmail.com
}

DOI: 10.15170/TVT.2021.06.03.06.

\begin{abstract}
Absztrakt
A 21. században a határon túli magyar közösség egyik legnagyobb kihívása, hogy megtalálja azokat az értékeket, amelyek által erösödhet és megmaradhat kisebbségi létben önszerveződés útján is. Napjainkban a vajdasági magyarság identitásának megőrzése szempontjából fontos célkitüzés anyanyelvű oktatásának, nyelvének, kultúrájának megőrzése a jelentős népességfogyás ellenére is. Számos civil szervezet, müvelődési intézmény tevékenykedik, amely az anyanyelvi kultúra megtartását tüzte ki célul, s feladatként vállalta a kulturális identitás megőrzését.

A tanulmány általánosságban kitér a vajdasági Tisza mente, ezen belül is egy kisváros lokális és kulturális örökségének elemeire, a müvelödési intézmények közösségépítő és helyi identitástudatot formáló tevékenységére. Áttekinti, hogyan szolgálja egy cselekvő közösség megmaradását és identitásának erösítését a vidéki, hagyományos örökség, a helyi értékek, a kulturális, az épített és a szellemi örökségek, valamint miként segítik ezek a közösségi életet.

Kulcsszavak: lokális identitás, nemzeti-kulturális identitás, vidéki örökség, helyi érték, települési értéktár
\end{abstract}

\begin{abstract}
In the $21^{\text {st }}$ century, one of the biggest challenges for the Hungarian community across the border is to find the values by which it can be strengthened and remain a minority through self-organization. Nowadays, the preservation of the mother tongue education, language and culture is an important goal for the preservation of the identity of the Hungarians of Vojvodina, despite the significant population decline. There are a number of non-governmental organizations and cultural institutions that aim to maintain their native language culture and have undertaken the task of preserving their cultural identity.

"The study covers in general the elements of local and cultural heritage of the area along the river Tisza, including those of a small town called Senta, as well as the community-building activities of cultural institutions, which shape and strengthen the local identity. The study reviews how rural, traditional heritage; local values; cultural, built and intellectual heritage, and the community life associated with them serve the survival of an active community and reinforce its identity."
\end{abstract}

Keywords: local identity, national-cultural identity, rural heritage, local value, local collection of values 


\section{Bevezetés}

A 21. században a határon túli magyar közösség egyik legnagyobb kihívása, hogy megtalálja azokat az értékeket, amelyek által erősödhet és megmaradhat kisebbségi létben, multikulturális környezetben, akár önszerveződés útján is. Napjainkban a vajdasági magyarság identitásának megörzése szempontjából fontos célkitüzés anyanyelvü oktatásának, nyelvének, kultúrájának megőrzése a jelentős népességfogyás ellenére is. Számos civil szervezet, művelődési intézmény tevékenykedik, amely az anyanyelvi kultúra megtartását tüzte ki célul, s feladatként vállalta a kulturális, valamint az etnikai identitás megőrzését.

A kulturális identitás fő sajátosságai: közös szabályok, közös jelképek és mítoszok, közös ős. Az állami-politikai határok nem azonosak a kulturális nemzet határaival, mint ahogyan a vajdasági magyarság kulturálisan egy más országban élő nemzettel azonosul.

Újvári Edit összegzése alapján a kulturális identitás a közösség - és benne az egyén azonosságtudatát alakító értékek, normák, viselkedésminták, tudás-és hagyományrendszerek összessége (ÚJVÁRI 2009). A kulturális közösséget egyének alkotják, olyan egyének csoportja, akik ugyanazt a kulturális értéket becsülik, akiket a közös identitás köt össze azonos kulturális jegyek alapján, s szeretnék a közös identitást megörizni és továbbfejleszteni (SIMOVIĆ-HIBER KARTAG-ÓDRI 1997).

A kulturális közösség, ezáltal a kulturális identitás nem minden esetben egyenlő az etnikai közösséggel, föleg a többnemzetiségü közösségekben nem célszerü kiegyenlíteni a két fogalmat. Egy kultúrnemzet meglétét a kulturális identitás biztosíthatja. Az etnikai csoport kultúrnemzeti megfogalmazása az államnemzetivel ellentétben állhat (KEMÉNYFI 2001). Veres is utal tanulmányában arra, hogy Közép-és Délkelet-Európában a nemzeti kisebbségek esetében a kultúrnemzet eltér az államalkotó nemzettől (VERES 2005).

Keményfi a kultúrnemzet fogalmát az etnikai csoport értelmezése felöl közelíti meg, vagyis az etnikai csoport a folyamatosan változó társadalmi helyzetektől független közösség. Létét nem csak változatlan kulturális jegyei, hanem a csoport történeti kontinuitása is igazolja (KEMÉNYFI 2001). A vajdasági magyarság, a történelem viharaiban kisebbségi léthelyzetbe sodort nemzeti közösség saját kulturális örökségét, hagyományát egy másik országban élő nemzet kulturális örökségével, hagyományával azonosítja, és nem azonosul az államalkotó nemzettel. A kultúrnemzet fogalma amely először Németországban vált ismertté a 20. század elején -, napjainkban elterjedt a Kárpátmedencében élö magyar kisebbségek elemzése esetében is. Mikroszinten a kulturális-nemzeti identitás „az egyén beállítottságától, erőfeszítésének, értékrendjének és érdekeinek alakulásától függ" (KOVÁCS 2016:106).

A vajdasági magyar kultúra a kulturális élet minden területén az egyetemes magyar kultúrához való tartozást kívánja megvalósítani, ugyanakkor a többségi kultúrával is folyamatosan kapcsolatban kell állnia (VAJDASÁGI MAGYAR KULTURÁLIS STRATÉGIA 2012-2018, http://mnt.org.rs). A vajdasági magyar nemzeti kultúra egyszerre kisebbségi kultúra Szerbiában és Vajdaságban, többségi kultúra a többségében magyarlakta településeken, nagyvárosi kultúra és a kistelepüléseken élök kultúrája is.

Az észak-bácskai és az észak-bánáti körzet a leginkább magyarlakta térség a Vajdaságban. ÉszakBánát körzet bácskai oldala (Horgos, Magyarkanizsa, Zenta, Ada, Mohol, Péterréve és Óbecse) képezik a tömbmagyarságot, ezeken a településeken a népességben kétharmadosnál nagyobb aránnyal képviseltetik magukat a magyarok (VAJDASÁGI MAGYAR KULTURÁLIS STRATÉGIA 2012-2018, http://mnt.org.rs). A tömbben élő magyarság a mindennapjaiban és a közéletben is anyanyelvét gyakorló, valamint az önkormányzatban döntéshozatallal vagy részben döntéshozatallal rendelkező közösség. 
A Csurgó-Légmán szerzőpáros Sen Amartya tanulmánya alapján kifejti, hogy a közösségek szempontjából két integráló mechanizmust tárhatunk fel: az első a közösség identitásformáló szerepéhez kötődik, ebben az esetben a közösségi, kollektív identitás jelenti az integráció alapját, a másik esetben az integráció a közösség intézményi jellegéhez kapcsolódik. Az intézményi jellegnél az egyén közösségbe szerveződve vesz részt a közösség tevékenységeiben, a közösség biztonságot és identitást ad az egyénnek. Az intézmények szerepe abban mutatkozik meg, hogy meghatározzák a közösség mindennapjait, és ellátják a közösség számára szükséges funkciókat. (CSURGÓ-LÉGMÁN 2015:3).

\section{A kutatás módszere}

A kutatás során 2021 februárjában és márciusában öt interjúalannyal félig strukturált interjú keretében beszélgettem, az interjúalanyok a zentai közélet, az idegenforgalmi és müvelődési intézmények kiemelkedő kulcsszereplői. Az interjú során választ kerestünk arra, hogy mi vonzza a látogatókat egy-egy vidéki kistelepülésre: Zentára, Magyarkanizsára, Adára. Lehet-e turisztikai termék a helyi kultúra és fesztivál, pl. a Városnapok rendezvénysorozat keretében megszervezett zentai csata programsorozat, a Tiszavirág Fesztivál, a Halászléfőző Fesztivál stb.) Erősítheti-e a települési értéktárban helyet kapó épített, kulturális örökség a településen élők és elszármazottak identitástudatát. Az interjúalanyok rávilágítottak arra, mely nemzeti, települési értékeknek van a legnagyobb szerepe a lokális identitás kialakításában, erösítésében Zentán és a Tisza mentén, és mit kellene tenni, hogy még vonzóbbá váljanak a nemzeti, települési értékek. A települési és külhoni érték, a turizmus és gazdaság összefüggéseire kerestük a választ olyan nyereséges, sikeres vállalkozások bemutatásával, amelyek egy-egy települési értékhez kapcsolódóan a helyi termékeket népszerüsítik. Tapasztalati megfigyeléssel elemeztük Zenta turisztikai erőforrásait.

Az interjúkészítés mellett a másodlagos adatok begyüjtésénél áttekintettem a zentai önkormányzat és a vajdasági magyar közösséget érintő idegenforgalmi fejlesztési stratégiát, a zentai idegenforgalmi iroda éves jegyzőkönyveit, a megvalósult és folyamatban levő művelődési és idegenforgalmi projektumokat, a Vajdasági Magyar Értéktár Tisza menti településeire vonatkozó helyi értéktárának épített és kulturális értékeit, szecessziós emlékeit.

\section{Következtetések}

Tanulmányomban a kiindulópontot az a meghatározás adja, hogy a vajdasági magyar közösség olyan kultúrnemzet, amelynek tagjait a közös kultúra és hagyomány, az azonos eredettudat, a közös identitás és összetartozás-tudat köt össze (KEMÉNYFI 2001), tehát a vidéki örökség és identitás összefüggését a kultúra felöl közelítem meg.

A fentebb említett két integráló mechanizmus (kollektív identitás és intézményi jellegü identitás) folyamatában a vajdasági Tisza mente, ezen belül is föleg egy kisváros, Zenta lokális és kulturális örökségének elemeit, a müvelődési és idegenforgalmi intézmények közösségépítő tevékenységének szerepét feltételezzük, amelyek a helyi identitástudatot formálják és erösítik. Feltételezzük továbbá, hogy egy cselekvő közösség megmaradását és intézményi jellegű identitását a vidéki, hagyományos örökség, a hozzájuk kapcsolódó közösségi élet, a helyi értékek, a kulturális, épített, szellemi örökségek befolyásolják. Igény mutatkozik a lokalitás és a vidékiség iránt, a fejlődés lehetőségét, a vállalkozások müködését a helyi sajátosságokra épülő idegenforgalom segíti.

\section{Kutatási eredmények}

\subsection{A vidéki örökség hagyományos intézményei}

Zenta az észak-bánáti körzet bácskai oldalán elhelyezkedő, többségében magyar nemzetiségü emberek által lakott település, kulturális sokszínüség, változatos nemzetiségi-kulturális összetétel 
jellemzi, a városi/kisvárosi tömb csoportjába tartozik. A 2002-es népszámlálás adatai szerint Zenta községben, melyhez négy falu is tartozik, 25.568 lakos élt, ebből 20.587 ember vallotta magát magyar nemzetiségünek. A 2011-es népszámlálás adatai szerint a községben a 22.961 lakosból 18.441-en vallották magukat magyar nemzetiségünek (SZERBIAI STATISZTIKAI HIVATAL, http://stat.gov.rs). Több mint tíz százalékkal csökkent a lakosok száma a 2002-es népszámlálási adatokhoz képest a nagyfokú elvándorlás és az alacsony natalitás miatt.

A helyi, föleg magyar kultúrát képviselő intézmények sorában kiemelkedő tevékenységet végez a Zentai Történelmi Levéltár, a Thurzó Lajos Művelődési-Oktatási Központ, a Zentai Magyar Kamaraszínház és a zentai székhelyü Vajdasági Magyar Müvelődési Intézet. Az első három lokális intézmény a magyar közösség identitásának őrzése és fejlesztése szempontjából kiemelt jelentőségü a kisebbségi jogok érvényesítésével megbízott Magyar Nemzeti Tanács döntése értelmében. Ez azt jelenti, hogy a Magyar Nemzeti Tanács törvényben szabályozott keretek között támogatja a magyar közösség szempontjából fontos müvelődési intézmények közvetlen fejlesztését, fennmaradását.

A kiemelt jelentőségű intézmények a regionális és lokális identitást is nagyban meghatározzák, és a vidéki örökség kultúrközvetítő intézményei egy-egy helyi közösség életében. Feladatuk a lokális és regionális közösségépítő szerep erősítése; a kortárs kultúra bemutatása; az esélyegyenlőség biztosítása a nyitott kultúra eszközrendszerével; a nemzeti közösségek kultúrájának támogatása; a magyar közösség nemzeti identitásának erősítése fesztiválok, rendezvények révén; megemlékezések a nemzeti ünnepekről és a magyar kultúra jeles alakjairól; az anyanyelvi kultúra magas szintü ápolása, a művészeti tevékenységgel foglalkozók, alkotók támogatása.

Az 1950-ben alakult Zentai Történelmi Levéltár 1967-tôl regionális levéltárrá vált, lefedve és begyüjtve a Tisza mente községeinek levéltári anyagait. Így a mai napig öt községben munkálkodik: Magyarkanizsán, Adán, Óbecsén, Szenttamáson és Zenta községben. Az intézmény a levéltári iratanyagok feldolgozása, tartós megörzése mellett kiadói tevékenységet is folytat magyar és szerb nyelven, könyvbemutatókat, kiállításokat, előadásokat, konferenciákat, szakmai tanácskozásokat, levéltári-pedagógiai foglalkozásokat szervez, tudományos, közmüvelődési teendöket is ellát.

Az 1977-ben alakult Thurzó Lajos Müvelödési-Oktatási Központ a Tisza mente (Magyarkanizsa, Csóka, Zenta, Ada községek) magyar müvelődési életét gazdagítja, magába foglalja a Városi Könyvtárat, a Városi Múzeumot és a Müvelődési Házat. Számos, a Magyar Nemzeti Tanács által kiemelt jelentőségü, regionális és tartományi szintü rendezvényt szervez: Énekelt Versek Fesztiválja, Hagyományaink ünnepe, Kálmány Lajos Népmesemondó Verseny, Zetna irodalmi fesztivál, Középiskolások Szín-és Filmmüvészeti Vetélkedője, Zentai Müvésztelep, a zentai csata emlékére kialakított városnapi rendezvénysorozat, a nemzeti és jeles ünnepek alkalmából megrendezett megemlékezések. Az intézmény keretében müködik a Települési Értéktár Bizottság (THURZÓ LAJOS OKTATÁSI-MÜVELÖDÉSI KÖZPONT, http://tlkk.org).

A hagyományos intézmények sorában ki kell emelni a 2009-ben alapított Zentai Magyar Kamaraszínházat, mely az egyik legfiatalabb magyar jellegü intézmény a Vajdaságban. A kamaraszínház elsősorban városi színház, tevékenysége viszont regionális. Az előadásokat a zentai közönség mellett a Tisza mente színház iránt érdeklődő lakossága is rendszeresen látogatja, Magyarországról és Zenta város testvértelepüléseiről is érkeznek színházkedvelők, valamint tájoló programjuk keretében, melynek fő támogatója a Magyar Nemzeti Tanács, bejárják egész Vajdaságot, az anyanyelvü kultúrát népszerüsítve a szórványtelepüléseken, iskolákban tantermi produkció keretében. Előadásaik ismertek Magyarországon és Erdélyben is, és kivívták a Kárpátmedence szakmai elismerését (ZENTAI MAGYAR KAMARASZÍNHÁZ, http://zentaimagyarkamaraszinhaz.com) Négy évvel ezelőtt indították útjára a Magyar Teátrumi 
Társasággal közösen a Teátrum Neked! nevet viselő fesztivált a vajdasági magyar közösség számára, mely óriási érdeklődésnek örvend.

Mindegyik müvelődési intézmény célja, hogy a helyben lakók művelődéssel, nyilvánossággal, társas együttléttel kapcsolatos óhaja és öntevékenysége találkozzon. A kulturális örökség a kollektív emlékezet része, és erősíti a kulturális identitást, nemzeti öntudatot. A lokalizáció akkor jár együtt a helyi társadalom kialakulásával, ha tagjai felismerik a közös érdekeiket, és együttmüködnek azokért. Általánosságban elmondható, hogy a 12-60 éves korosztályt szólítják meg az intézmények. A müvelődési jellegü programok nem minden esetben összpontosítanak kizárólag a hagyományőrzésre, céljuk a kulturális turisztikai kínálat gazdagítása. A két integráló mechanizmus, a kollektív identitás és a közösség intézményi jellegéhez kacsolódó identitás szorosan összekapcsolódik a hagyományos intézmények esetében, egymást kiegészítve.

A Tisza mentén, így Zenta községben is számos nonprofit civil szervezet, müvelődési egyesület müködik, berkein belül hagyományőrző szakkörök (kézimunka szakkör, kézmüvesek, régi mesterséggel foglalkozók), együttesek (néptánccsoportok), társulatok (amatőr színtársulat, bábtársulat) tevékenykednek, az egyént a cselekvő közösség integrálja, amelyben a helyi kultúra létezik és gyökerezik, ezáltal a közösség intézményesül. Zenta községben több mint 80 aktív civil szervezetet jegyeznek, legtöbb a müvelödéssel és hagyományőrzéssel foglalkozó szervezet vagy müvelödési egyesület. A kisebb falvakban, településeken, ahol nincs hivatásos intézmény vagy annak fenntartására nincs mód, az egyesületeken, civil szervezeteken keresztül képviselik a kultúrát a magyar közösségekben, illetve vendégszereplésekkel, közös projektumokkal segítik a kulturális fennmaradást. A falvakban a rendezvények sorában kiemelt jelentőségü az aratóünnepség, a karácsonyi népszokások vagy a Szent István-naphoz kötödö kenyérszentelö ünnepségek. A helyi kultúra a rendezvények által közösségformáló erővel bír, átörökítik a hagyományokat az utókorra és lehetővé teszik a hatékony idő felhasználását is. A hagyományőrző, népi tevékenységek mellett van egy modern vonulata is a közösségfejlesztésnek (modern tánckörök, kórusok, mazsorettcsoport), így fiatalabbakat és idősebbeket is megszólítanak. A kisvárosi, vidéki települések felemelkedését a helyi erőforrásokon és a helyi részvételen alapuló fejlesztések teszik lehetővé.

\section{Vidéki örökség és lokális identitás}

Vajdaság területén számos olyan kulturális érték található - legyen az épített vagy szellemi -, amely turisztikai vonzerőként mutatható be a hazai, anyaországi és külföldi vendégeknek. A tájegység számos olyan helyszínnel, emlékhellyel rendelkezik, amely a magyar történelemhez kötődik. Az emlékhelyek közül sok felújításra szorul. Ezek mellett a térségre jellemző szokások és a szellemi örökség is gazdag, amelyeknek egy részét jobban kellene prezentálni. (A VAJDASÁGI MAGYAR KÖZÖSSÉGET ÉRINTÖ IDEGENFORGALOM FEJLESZTÉSI STRATÉGIÁJA 2018, http:// prosperitati.rs).

A zentai székhelyü, 2003-ban alapított Vajdasági Magyar Müvelödési Intézet a vajdasági magyar szellemi élet fontosabb jelenségeit igyekszik archiválni és a magyar müvelődési tevékenységet végző intézményeket, szervezeteket fogja össze a Vajdaságban. Ez az intézmény vállalta fel a Vajdasági Magyar Értéktár, ezen belül a települési értéktár bizottságok munkájának koordinálását, azzal a törekvéssel, hogy segítse a vajdasági magyarlakta településeket, a magyar közösségeket a mozgalomba való bekapcsolódásban, saját értékeik átmentésében. „A város, mint centrum sok tekintetben szemben áll a vidékkel, mint perifériával. Az értékteremtés, értékmegörzés tekintetében más és más módon kell megközelíteni az egyes település típusokat. Figyelembe kell venni a helyi sajátosságokat, és azokat egységben kell kezelni” (SZAKÁLI 2019:56).

A helyi értékek feltárásában gyakran a település lakóit is bevonhatják, mert ők az elsődleges értékmegőrzők, rajtuk múlik a hagyományok ápolása, átörökítése. Ezáltal az egyén és a közösség 
tevékenysége összefonódik, az egyén a cselekvő közösség részévé válik egy társadalmi felelősségvállalásban. Minden településnek lehet rejtett értéke, amely a közösség fejlődését segítheti és szolgálhatja. Az értékfeltáró munka lényege - az integráló mechanizmus folyamatában - az egyéni és közösségi, vagyis kollektív identitástudat erősítésében bontakozik ki. Vajdaságban a települési értéktárakat föleg müvelődési egyesületek és nonprofit civil szervezetek alakítják, és az integráció a közösség intézményi jellegéhez kapcsolódik. A bizottságnak bárki tagja lehet, aki szakmai rátermettségével, példamutatásával részt tud vállalni az öntevékeny feladatok ellátásában. Mindenképpen eredményesebb egy bizottság, ha szakmailag olyan tagok végzik a feladatokat, akik „jól ismerik a települést, annak történetét, hagyományait, lakosait, vagy esetleg egy speciális szakterületen vannak otthon (pl. történész, helytörténész, néprajzos, pedagógus, biológus, stb.). Az ö tudásuk ugyanis elengedhetetlen a helyi értékek felkutatásához, a javaslatok elkészitéséhez" (VÁZSONYI 2020: 342.).

Azok az intézmények, amelyek a változást hangsúlyozzák, el kell, hogy kötelezzék magukat a részvétel kultúrája iránt. Ez úgy lehetséges, ha „bevonják a lakosságot a városi örökség védelmébe, megőrzésébe, gondozásába és kezelésébe, ami a közjó iránti felelösséget növeli, egyaránt hozzájárulva a személyes és közösségi identitás megteremtéséhez" (INTERREG CENTRAL EUROPE, https://interreg-central.eu).

A Tisza mente bácskai oldalán (Magyarkanizsa, Zenta, Ada és Óbecse községekben, a városokban és a hozzájuk tartozó falvakban) a következő települési szakterületi kategóriákban jelöltek értékeket:

- Agrár-és élelmiszergazdaság: 2 érték

- Épített környezet: 36 érték

- Kulturális örökségek: 35 érték

- Természeti környezet: 9 érték

Bácskai oldalon a Tisza menti települési értéktárak vonatkozásában a legnépesebb kategória az épített környezet, ezt pedig közvetlenül a kulturális örökség követi.

\section{1. Épített környezet}

Az épített környezet témakörén belül az embert körülvevő környezet fenntartásához kapcsolódó szellemi termékek jelennek meg, legnagyobb számban a feszületek, kápolnák, szobrok, szakrális kisemlékek szerepelnek, majd ezt követik a templomok, középületek és a népi építészet emlékei, pl. a napsugaras díszítésű oromzatú házak Tornyoson, Zentán és Óbecsén. Magyarkanizsa község egyik kis településén, az 1811 lélekszámú Kispiacon 12 szakrális kisemlék került be a települési értéktárba. A településen a templom csupán 1945-ben épült fel, a keresztek voltak azok a helyek, ahol a járókelők vagy a munkába igyekvők megálltak egy-egy fohász erejéig (VAJDASÁGI MAGYAR ÉRTÉKTÁR, http://ertektar.rs). Az Ada községhez tartozó Törökfalun, Völgyparton és Valkaisoron is 8 kereszt található kinn a határban, a dűlőutak mentén. Ezek az emlékek kultikus funkcióval bírnak, és településszerkezeti szempontból is jelentősek. „Magasan kiemelkednek a földböl, s tanúskodnak azokról az emberekröl, akik e kereszteket Isten dicsőségére felállították, valamint azokról is, akik ma gondot viselnek róluk" (VAJDASÁGI MAGYAR ÉRTÉKTÁR, http://ertektar.rs). Az adai Szentháromság-templom tornya az idők során a város jelképévé, helyi jellegzetességé vált egyedülálló szerkezete miatt, de a tájház és a díszített mükőkapuoszlop is említésre méltó a településen. 


\section{1. ábra. Az adai Szentháromság-templom tornya}

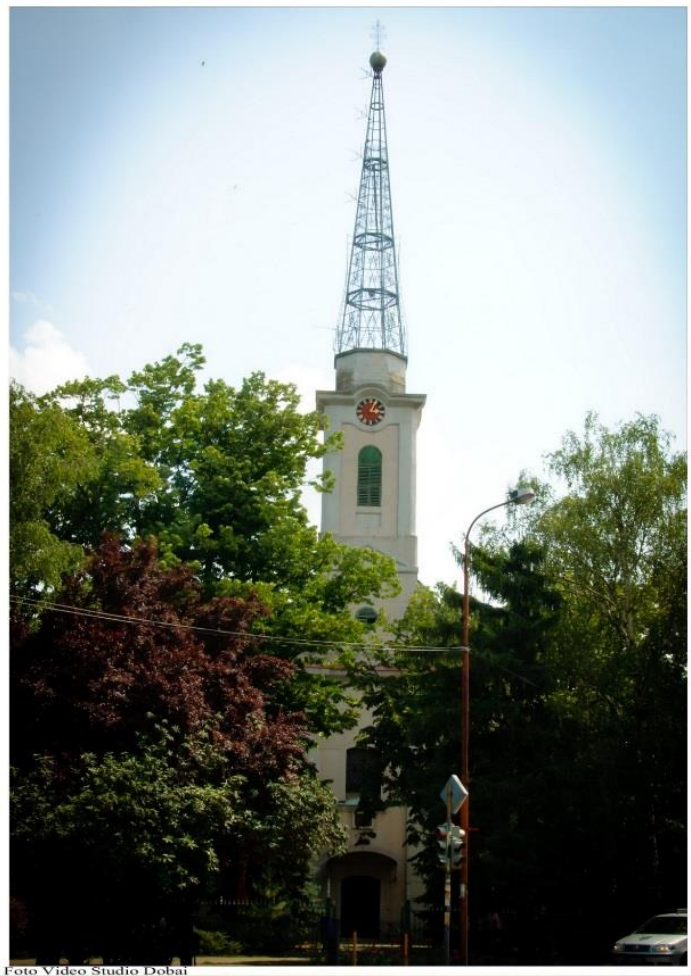

Forrás: http://ertektar.rs/ertektar/ertek/Az-adai-Szentharomsag-templom-tornya-/72

A zentai települési értéktárban 36 érték kapott eddig helyet, ebből a kisvárosban 13, a községhez tartozó faluban 8 épített örökséget jegyeznek a települési értéktárban. Zentán vannak műemlék jellegü és védettnek nyilvánított épületek, a helyiek számára ezek az épületek jelentős építészeti örökségek. Kiemelünk néhány épületet, amelyek a Vajdasági Magyar Értéktár Települési Értéktárában is helyet kaptak. Interjúalanyaim arra a kérdésre, hogy mely települési értékeknek van a legnagyobb szerepe a lokális identitás kialakításában vagy erősítésében Zentán és környékén, egyöntetüen a szecessziós stílusú és kissé romantikus hatású Zentai Városháza (1912-1914) tekintélyt parancsoló épületét nevezték meg a fötéren. Az épület fennállása óta Zenta jelképévé vált, Kovács Frigyes budapesti müépítész tervezte. A városháza látványa megihletett számtalan müvészt, akik a legkülönfélébb formákban, képzőmüvészeti alkotásokban örökítették meg az épületet, továbbá számos kiadvány, dokumentum, helyi okmánybélyeg dísze is volt már. Legfelső szintjén kapott helyet a Zentai csata-emlékkilátó, ahonnan pompás kilátás nyílik a városra és a környékre (VAJDASÁGI MAGYAR ÉRTÉKTÁR, http://ertektar.rs). 


\section{2. ábra. Zentai Városháza (1912-1914)}

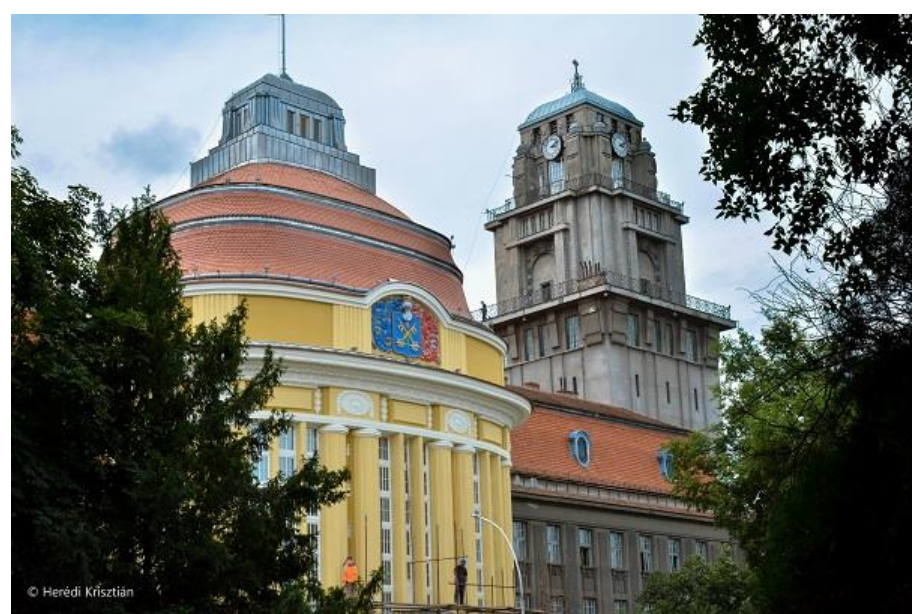

Forrás: Herédi Krisztián fotója (http://www.zentasenta.co.rs/hu/6/a/6/816/2016_07_18_a.html/1)

3. ábra. Zentai Városháza (1912-1914) belső tere.

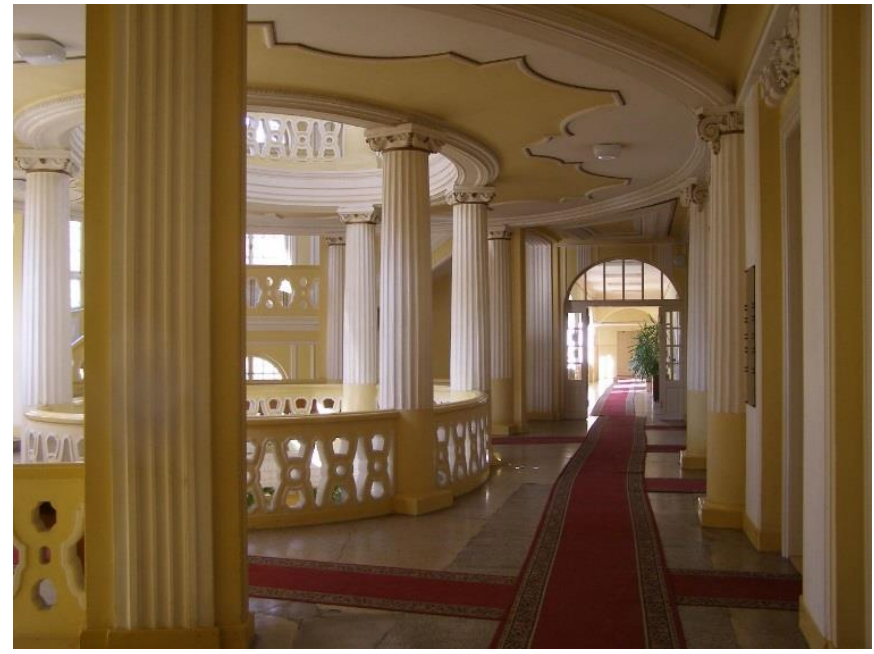

Forrás: http://ertektar.rs/ertektar/ertek/A-zentai-Varoshaza-epulete/157

A Zentai Gimnázium (1884-1910) ma is a fötér meghatározó épülete, díszes főhomlokzata magyaros stílusban készült. Tervezője Berzenczey Domonkos, Zenta föépítésze. Magyar Ede, szegedi építész tervezte a Royal Szállót (1910-1911), melynek építészete a modern elemek felé mutat, de szecessziós elemek is díszítik az épületet, és egy több mint száz éves iskolaépület is meghatározó a helyi identitás szempontjából, ez pedig a szintén müemlékké nyilvánított Thurzó Lajos Általános Iskola (1913-1914).

A szakrális építészeti örökségek az európai kultúrához való végleges visszatérést, a több mint ezeréves fennmaradás lehetőségét szimbolizálják. Számos egyházi kulturális rendezvény helyszíne a Jézus Szent Szive templom és a zentai csata emlékére épített Lisieux-i Kis Szent Terézemléktemplom. Az épített örökségek kategóriájában kapott helyet a Plébániapalota épülete, a Páduai Szent Antal-templom, a görögkeleti Szent Mihály Arkangyal-templom és a tornyosi szecessziós stílusban épült Magyarok Nagyasszonya-templom. 
4. ábra. Lisieux-i Kis Szent Teréz-emléktemplom. Kulturális örökség.

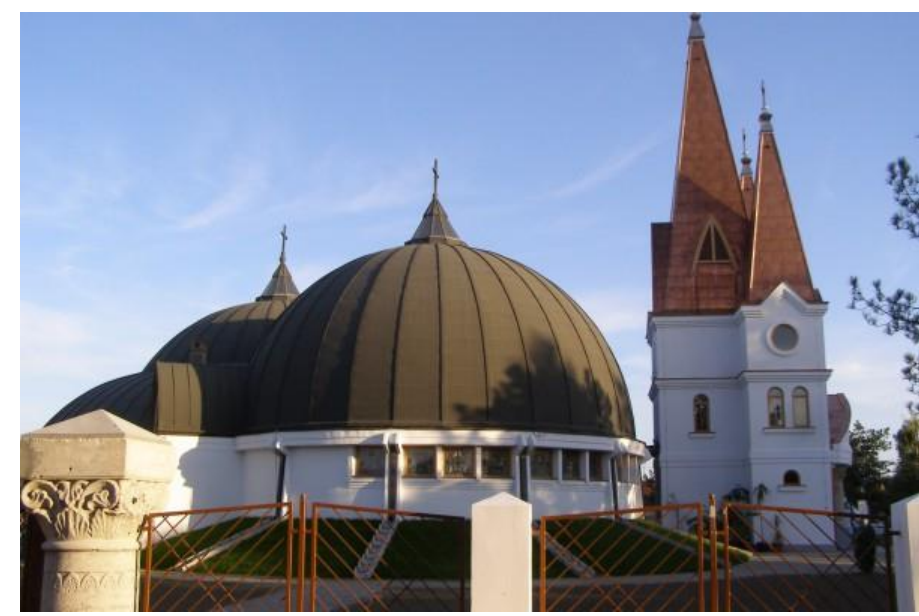

Forrás: Vajdasági Magyar Értéktár (http://ertektar.rs/diakertekorok/ertek/Lisieux-i-KisSzent-Terez-emlektemplom--/174)

Interjúalanyaim véleménye, hogy a szakrális tér az egyén és a közösség integráló szerepét hangsúlyozza. A vallásosság megváltoztatja a térbeliséget, kimozdulással, helyváltoztatással, mobilizációval jár. A nyilvánosság felvállalásával a közösség összetartozását juttatja kifejezésre. Kinyilvánítják hovatartozásukat, s egyfajta nemzeti-vallási szimbólumként müködtetik a szakrális teret, a találkozókat és az egyházzenei fesztiválokat, a szakrális tér kulturális rendezvények színhelyévé válik (SZÖKE 2015). Nemcsak a település lakói vesznek részt az ünnepségeken, hanem az elszármazottak is, akik olykor-olykor hazatérnek szülőhelyükre.

Interjúalanyaim kiemelték a Külhoni Nemzeti Értéktárban szereplő Zentai Tüzoltólaktanyát (1903-1904) is, amely szecessziós stílusban készült a magyar népmüvészet elemeinek felhasználásával, alkotója Lechner Ödön tanítványa, Lajta Béla (1873-1920), a XX. század magyar építészetének kiemelkedő alakja (VAJDASÁGI MAGYAR ÉRTÉKTÁR, http://ertektar.rs). Az újvidéki Tartományi Mủemlékvédelmi Intézet védetté nyilvánította az épületet 1974-ben, majd 1991-ben a jelentős müemlékek közé sorolták.

A Külhoni Nemzeti Értéktárban szerepel egy zentai kulturális érték, egy neves történelmi esemény, A gyözedelmes zentai csata (1697. szeptember 11.), amely a zentaiak identitástudatának erősítésében kiemelten fontos. Savoyai Jenő herceg és hadvezér a keresztény seregek élén győzelmet aratott a törökök felett Zentánál, s ezzel a csatával az európai összefogás megdöntötte Magyarországon a török uralmat.

\subsection{Kulturális örökség}

A kulturális örökség tárgykörét szellemi és tárgyi javak, népművészet és népi mesterségek, néprajz, táncmüvészet, irodalom, nemzeti és történelmi emlékhelyek, munkásságukban kiemelkedő személyiségek képezik. Számos közösségnek van olyan személyisége, aki példakép lehet a saját településén.

A teljesség igénye nélkül kerül megemlítésre néhány kulturális örökség: Moholon jellegzetesek az úrnapi virágszőnyegek, ebből az alkalomból Úrnapján egyre több vendég érkezik a faluba. A virágszőnyegek motívuma évenként változik, a díszítők előre megbeszélt, azonos témakörü képeket készítenek, viszont a főoltár virágszőnyege minden évben a koronás magyar címert ábrázolja. Alapvetően a falubéli asszonyok tisztsége a virágszőnyegek elkészítése, anyáról leányra száll a hagyomány (VAJDASÁGI MAGYAR ÉRTÉKTÁR, http://ertektar.rs). Szintén Ada községben három falu: Valkaisor, Völgypart és Törökfalu hármas ünnepségsorozatot szervez: 
Valkaisoron az Aratóversenyt, ahol hagyományos módon lekaszálják a búzát; Völgyparton a Jár a malom címü rendezvényt, ahol megőrlik a learatott gabonát, valamint Törökfalun a Kenyérszentelöt, amikor az új búzából megőrölt lisztből megsütik az újkenyeret, amit a közösség megszentel (VAJDASÁGI MAGYAR ÉRTÉKTÁR, https://ertektar.rs). Mindhárom ünnepnek közösségmegtartó ereje van, összekovácsolja a helybelieket az előkészületektől kezdve, és összehozza a környékbeli és határon túli közösségeket, ahol egymás kultúráját, munkásságát megismerik. A lokális ünnepek azt tudatosítják az emberekben, hogy melyik csoporthoz tartoznak, megerősítik egy-egy közösség összetartozását, modellálják a kollektív tudatot és emlékezetet (PETI 2005). Horgoson és Óbecsén a néphagyományok említhetök a kulturális örökségek között: a horgosi csárdás, az óbecsei népi gyermekjátékok és a tamburazene, valamint a Than-emlékház, melynek feladata a tudományok és a müvészetek népszerüsítése az iskoláskorú gyerekek és fiatalok körében, a müemléképület pedig kortörténeti, városképi, turisztikai és kulturális örökségi jelleget is hordoz (VAJDASÁGI MAGYAR ÉRTÉKTÁR, http://ertektar.rs).

A zentai kulturális örökség kategóriában a település szempontjából számos neves, kiemelkedö személy életműve kapott helyet és maradandó emléket a természet- és a társadalomtudományok területén: Bugarszky István bölcsészdoktor, kémikus, egyetemi tanár, Dudás Gyula történész, tanár, közíró, Thurzó Lajos költő, újságíró, Fekete Mihály matematikus, egyetemi tanár, Bodor Anikó népzenekutató, Szeli István akadámikus professzor és az interkulturalizmus jegyében Jovan Đorđević író, az újvidéki és a belgrádi Szerb Nemzeti Színház alapítója, a jelenlegi szerb himnusz szerzője, Jovan Muškatirović, népmüvelö, író, Stevan Sremac kiemelkedő szerb prózaíró. Említsük meg azt is, hogy az emlékezet fenntartásában a következő feladat kell, hogy legyen a neves zentai szülöttek szülőházának megjelölése. A települési értéktárban ugyan nem szerepel, de nagy érdeklődésre tart számot néhány zentai és magyarkanizsai közösségi rendezvény, amely a müvelődési élet különböző területeit fedi a kortárs kultúrától a hagyományos kultúráig, sok látogatót vonz a környékről és külföldről, közösségépítő, hagyományteremtő jelleggel bír. Ilyen jellegü rendezvény Zentán a Karácsonyi kavalkád, az I love Zenta fesztivál, az Interetno fesztivál, a Mosolytenger gyermekfesztivál és a nemzetközi Hölégballon-találkozó. Magyarkanizsán a Szent István-nap és újkenyér-ünnepének van régi hagyománya, valamint közkedvelt a Jazzfesztivál és a Malomfesztivál.

Kárpáti Árpád-Rigó Róbert a lokális, helyi identitást a területi identitás jellemzőjeként említi, véleményük szerint ismét erősödik a lakóhelyhez és helyi közösséghez tartozás élménye. A lakóhely magába foglalhat különböző méretü és jellegü területi egységeket, a néprajzi tájegységtől a járáson át a kistérségig, de akár városrészt, kerületet is jelenthet (Kárpáti Árpád-Rigó Róbert 2019).

A lokális identitás érzelmi kötődés a helyi közösséggel, a lakóhely természeti, kulturális értékeivel, hagyományaival, továbbá az identitást erösítheti a települési tájházak, múzeumok, nonprofit egyesületek közösségépítő, értékfeltáró tevékenysége. A fennmaradt hagyományos örökségek felderítése egy cselekvő közösség megmaradását szolgálja. Az egyén számára a család, a barátok, a településhez kötődő emlékek, élmények a helyben tartó erőt is jelenthetik, integráló erővel bírnak, az egyén szívesebben tér vissza abba a helyi közösségbe, ahova kötődik, ahol erősödött az egyéni és kollektív identitástudata.

\section{A vidéki örökség szerepe az idegenforgalomban}

Az átörökíthető helyi értékek gyüjtése, felkutatása, kidolgozása idegenforgalmi és gazdasági erőforrássá is válhat, amely a cselekvő közösség megmaradását is szolgálhatja egy-egy településen, régióban. A Tisza mentén ,, a turisták a kulturális turizmusnak több termékfajtáját vehetik igénybe, igy a szecesszió épitett örökségét bemutató és a helyi termékek megismerésére irányuló tematikus utakat, túrákat vagy a néphagyományokra épülö rendezvényeket” (TÖZSÉR 2019:50). Zentán a Városi Múzeum gyakran szervez tematikus kulturális utakat, mert igény mutatkozik rá a helyiek 
részéröl, kedveltek az épített, a kulturális és a természeti örökséget bemutató helyi és környékbeli útvonalak.

Csurgó Bernadett-Szatmári Anita tanulmányukban Christopher Ray (1998) kultúra-gazdaság elméletére hivatkoznak, ahol a kultúra-gazdaság módjait emelik ki a területi alapú vidékfejlesztésben. Az egyik müködési mód szerint a kulturális erőforrások területi reklámként használhatók fel, s ezáltal erősítik a területi identitást, a másik mód alapján a kulturális erőforráson alapuló fejlesztést a helyi közösség végzi el (CSURGÓ-SZATMÁRI 2014: 34). Lokális és regionális identitáserősítés szempontjából a kultúra-gazdaság elmélet kulturális erőforráson alapuló fejlesztésének vajdasági példája lehet a Külhoni Nemzeti Értéktárban is helyet kapó zentai csata köré épített imázs, melyet a zentai önkormányzat és Idegenforgalmi Szervezet több mint nyolc évvel ezelőtt kezdett kialakítani és felépíteni a helyi intézmények és civil szervezetek bevonásával. A Zentai csata (1697. szeptember 11.) a törökellenes felszabadító háború egyik legjelentősebb csatája volt, a szövetséges keresztény sereg Savoyai Jenő herceg vezetésével aratott győzelmet a török hadakon. Ezzel a csatával az európai összefogás megdöntötte Magyarországon a török uralmat, és elkezdődtek a törökkel a béketárgyalások, amelyek az 1699-ben megkötött karlócai békéhez vezettek. A Zentánál megmentett Bécs eseménye jelentős helyet foglal el a magyar történelemben, ezen kívül kiemelten fontos eleme a zentaiak identitástudatának. A helyiek felismerték a kulturális és turisztikai lehetőségeket a történelmi esemény kapcsán, s a kor kívánalmainak megfelelően „modernizálják” a helyi érték átörökítését úgy, hogy igyekeznek megtartani a kulturális tradíciókat ápoló kézmüves mühelyeket, amelyek a zentai csatát menedzselik. Így vált ismertté néhány helyi termék: a zentai csata emlékére készített, Savoyai Jenő és II. Musztafa arcképével díszített zentai marcipán, mely a települési értéktár agrár-és élelmiszergazdaság kategóriájában is helyet kapott, és története az 1897-es évekre nyúlik vissza az Almási-féle családi cukrászdában; a zentai csata emlékére készült "1697" elnevezésű borkülönlegesség a bor, a müvészet és a történelem találkozásának szellemében; a kézmüves manufaktúrával megalkotott Zentai csata csokoládé a Réel Chocolate kézműves mühelyben és más kézmüves mühelyekben készült ajándéktárgyak (bögrék, kulcstartók, hütőmágnesek, mézeskalácsok).

\section{5. ábra. Zentai csata bor-1697 és kézmüves csokoládé a Réel Chocolate kézmüves mühelyből.}

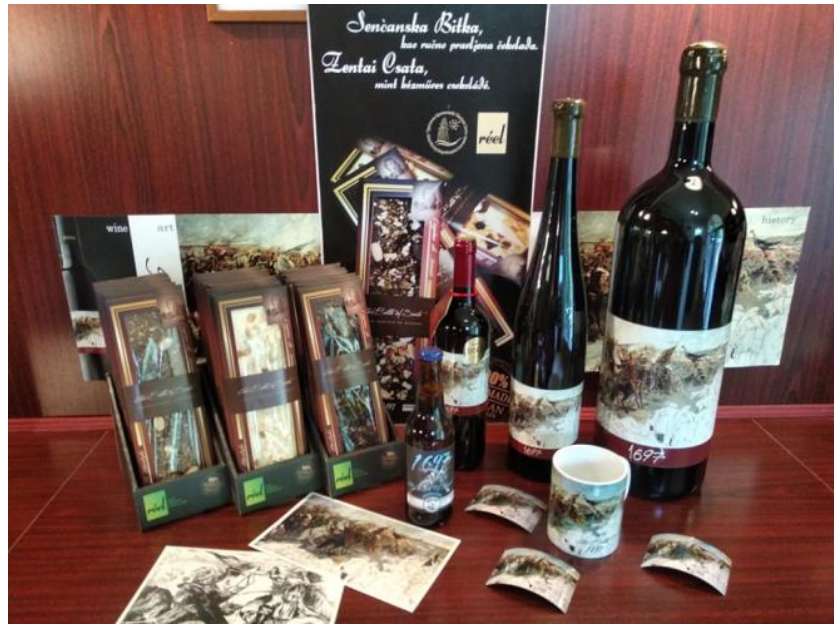

Forrás: a Zentai Idegenforgalmi Szervezet archívumából

A jeles történelmi eseményt a képzőmüvészetben, szobrászatban is megörökítették, majd az 1997 ben, a csata 300. évfordulója közeledtével a Tisza-parti városban emlékparkot létesítettek, szeptember 11-ét pedig a város napjává nyilvánították, s elhelyezték a zentai csata emléktemplom emlékkövét is. Ez a mai és korábban már említett Lisieux-i Kis Szent Teréz-emléktemplom. A 
történelmi esemény emlékezetét a Városi Múzeum állandó kiállítása, a Tisza-parti emlékhely és a városháza tornyában elhelyezett emlékkilátó biztosítja (VAJDASÁGI MAGYAR ÉRTÉKTÁR, http://ertektar.rs).

Az emlékkilátó az elmúlt évek során a város turizmusának egyik szimbólumává vált, a város testvértelepülésének, Budavár önkormányzatának és a Miniszterelnökség Nemzetpolitikai Államtitkárságának köszönhetően újabb értékes kiállítással gazdagodott a történelmi esemény 320. évfordulója alkalmából 2018-ban. A zentai csata népszerüsítésére jött létre a Zenta, 1697. rockopera a Soproni Petőfi Színház és a Zentai Magyar Kamaraszínház koprodukciójaként 2019ben. A werklifilmben a zeneszerző, Szarka Gyula, Kossuth-díjas énekes és Rúzsa Magdi énekel. A rockoperát a Kárpát-medence magyar lakta területein is bemutatták már, a felvidéki Dunaszerdahelyen, Magyarországon Gyulán, Szigetszentmiklóson és Esztergomban, valamint további vendégszerepléseket terveznek. A zentai csata programsorozat keretében éveken keresztül megszervezésre került a nemzetközi Hőlégballon-találkozó és verseny (sajnos, a járványhelyzet miatt a rendezvény az elmúlt két évben nem tudott megvalósulni). A találkozóra és versenyre a szerbiai nevezők mellett a szomszédos országokból (Magyarországról, Romániából, Szlovéniából) is érkeztek vendégek, versenyzők, akik látványos repülésükkel kápráztatták el a zentaiakat és környékbelieket. A hőlégballon repülést kipróbálhatták a város lakói mellett a környékbeli érdeklődők is, így nagy népszerüségnek örvendett a rendezvény tizenhat éven keresztül ÉszakVajdaságban.

A zentai csata emlékünnepére, amely egybe forrt a városnap több napos ünnepével, a régió számos településéről, Zenta külföldi testvértelepüléseiről is érkeznek vendégek. Zenta önkormányzata és a zentai Idegenforgalmi Szervezet két ízben pályázott sikeresen az Európa a polgárokért (Europe for citizens) elnevezésü pályázaton 2013-ban és 2016-ban, ennek köszönhetően egy kulturális fesztivál keretében 5 ország testvértelepülésének civil szervezetei és a város lakossága találkozhatott egymással, tapasztalatot cserélhettek, közelebb kerültek egymáshoz, és egymás települését is népszerüsítették.

A vajdasági oktatási intézmények diákjai rendszeres látogatói a múzeumi állandó kiállításnak és az emlékkilátónak, emellett a Rákóczi Szövetség és a Határtalanul diákutaztatási program keretében is számos fiatal választja úticélnak Zentát Szabadka, Palics szecessziós épületei és Pétervárad mellett. A Zentai csata nemzetközi sakktornát is a történelmi esemény tiszteletére szervezik meg. Az interjúalanyok elmondása szerint az egyik legnagyobb identitás-és közösségerősítő szereppel bír a zentai csata (1697. szeptember 11.) emlékezete lokális szinten. „Mindezen eredmények a közjó gyarapitását szolgálják (rámutatnak például, hogy ha egy térségben adott értékek mentén turisztikai útvonal alakul, miként profitálnak belöle az érintett térség lakói”(POLYÁK szerk. 2016: 27). A Zentai Idegenforgalmi Szervezet vezetőjének elmondása szerint a zentai csata imázsát turisztikai kínálatként menedzselik számos kisfilm alkotásával, internetes közösségi oldalakon, honlapon, idegenforgalmi kiállításokon.

A Tisza folyóhoz és a halászathoz köthető a Tiszai halászlé, amelyet szintén hungarikumként jegyeznek. Magyarkanizsán, Martonoson, Adán hagyományteremtő szándékkal indult útjára a halászléfőző-verseny és fesztivál, Zentán pedig a gasztrokultúra keretében a halászlé fogyasztásának van nagy hagyománya. A Papuli étterem messze híres a környéken, Szerbiában és Magyarországon is, így aki Zentára látogat vagy csak átutazóban van, biztos, hogy kipróbálja a Tiszai halászlevet.

A Tisza folyó a Tisza mente legértékesebb természeti-turisztikai erőforrása. A tiszavirág és a tiszavirágzás egyedülálló, látványos természeti jelenség - amellett, hogy hungarikum -, amelyet minden év júniusában mi is figyelemmel kísérhetünk. Idegenforgalmi szempontból is jelentős, a legenda szerint tiszavirágzáskor teljesülhetnek a szerelmi vágyak, ez pedig növelheti a Tisza-parti városok idegenforgalmát. Zentán és Magyarkanizsán közel tíz éve kerül megrendezésre a 
Tiszavirág Fesztivál, melynek keretében izgalmas filmvetítéseken, szórakoztató művelődési programokon, koncerteken, nemzetközi kajakversenyen és regatta-bemutatón vehetnek részt az érdeklődők. A természeti jelenség visszaköszön a vajdasági, Tisza menti népköltészetben, irodalomban, képzőmüvészetben is, Zentán egy gyönyörü Tiszavirág festmény függ a Royal Szálló falán, Magyarkanizsán pedig egy Tiszavirág emlékmüvet helyeztek el. A zentai Tiszavirág Fesztivál a városnapi programsorozat és az Interetno-Táncpanoráma müvelödési esemény mellett a leglátogatottabb és legközkedveltebb regionális rendezvény. Nemzetközi Interreg-pályázat keretében számos kulturális programot valósított meg a Thurzó Lajos Oktatási-Mủvelődési Központ a Tisza folyó témakörében Magyarkanizsával és Szegeddel együttmüködve.

A közeljövőben „A turisztikai vonzeröt a Tisza folyó mentén olyan összetett turisztika kínálattal érdemes fejleszteni, amely attraktiv lehet az ökoturizmus, a kulturális turizmus, benne az oktatási turizmus, a néprajz, a gasztronómia, a történelem és a múzeumok iránt érdeklödöknek" (KARANCSI et al 2020:8).

A fesztiválok kapcsán érinteni kell a helyi, minőséges termékeket előállító kézműves mühelyeket, régi mesterségeket (nemezelés, kosárfonás, gyöngyfüzés, szappankészítés, fafaragás, mézeskalácskészítés, Tisza menti fehérhímzés, mézkészítés). A kézműves tevékenységet folytatók amellett, hogy értékteremtéssel és hagyományőrzéssel foglalkoznak, civil szervezetekbe tömörülnek, néhányan kisvállalkozásokat alapítanak, és elengedhetetlen színfoltjai egy-egy kulturális rendezvénynek. Termékeiket olykor Zenta történelmi és müvelödési eseményeihez kapcsolva igyekeznek értékesíteni, mivel a legtöbb nonprofit civil szervezetbe tömörülö kézmüves nem bejegyzett gazdasági tevékenységet folytat, így hátrányba kerülnek azokkal szemben, akik profitáló, bejegyzett vállalkozás keretében müködnek. A fejlödésben el kell érni, hogy a helyi termékek turisztikai hasznosítása egy újabb fejlődési szakaszba léphessen, fontos a menedzselés, a védjegyhasználat és a kapcsolati rendszer erösítése. „A helyi termékekben rejlö lehetöségek eröforrásként való hasznositása társadalmi és gazdasági szinten is számos elönnyel jár. Segít megörizni a közösség tradicionális elemeit, környezetkímélö és környezetbarát termelést biztosit, megélhetést és jövedelmet teremt" (BERGHAUER et al 2020:71).

Magyarkanizsa még gyógyvizéről híres, a Csodakút Artézi Fürdő közkedvelt rehabilitációs gyógyfürdő. Szálláshelyek tekintetében Magyarkanizsa megfelelő számú vendégággyal rendelkezik, föleg ha a környezö kisvárosokhoz hasonlítjuk. A legtöbb szálláshely a gyógyfürdőben és annak közvetlen szomszédságában van. Ezen kívül számos magánszállást kínálnak a településen. A község falvaiban fejlödik a falusi turizmus, különféle rendezvényekkel csalogatják a helyiek a vendégeket. Zentán az utóbbi években folyamatosan bővül a vendégágyak számának kínálata, a településen egy hotel található, néhány magánszálláshely és panzió, összességében mégsem kielégítő és elegendő a szálláshelyek száma. 
6. A turisztikai kereslet jellemzői Zentán

1. táblázat. Turisták száma a bejelentett szálláshelyeken Zenta községben.

\begin{tabular}{|c|c|c|c|c|c|}
\hline \multicolumn{3}{|c|}{ Hazai turisták } & \multicolumn{2}{c|}{ Külföldi turisták } & Turisták száma \\
\hline ÉV & ÉRKEZÉS & $\begin{array}{c}\text { VENDÉG- } \\
\text { ÉJSZAKA }\end{array}$ & ÉRKEZÉS & $\begin{array}{c}\text { VENDÉG- } \\
\text { ÉJSZAKA }\end{array}$ & ÖSSZESEN \\
\hline 2015 & $\mathbf{1 7 6 1}$ & $\mathbf{3 9 6 5}$ & $\mathbf{2 3 3 5}$ & $\mathbf{7 6 8 9}$ & 4096 \\
\hline 2016 & $\mathbf{3 4 6 5}$ & $\mathbf{1 2 7 6 0}$ & $\mathbf{1 7 3 9}$ & $\mathbf{4 5 7 6}$ & $\mathbf{5 2 0 4}$ \\
\hline 2017 & $\mathbf{4 4 0 8}$ & $\mathbf{1 8 2 3 8}$ & $\mathbf{2 1 3 0}$ & $\mathbf{5 2 4 3}$ & $\mathbf{6 5 3 8}$ \\
& & & & & 7990 \\
\hline 2018 & $\mathbf{5 1 4 0}$ & $\mathbf{2 0 4 0 4}$ & $\mathbf{2 8 5 0}$ & $\mathbf{2 7 8 3 4}$ & \\
\hline 2019 & $\mathbf{5 3 2 4}$ & $\mathbf{2 2 5 0 6}$ & $\mathbf{2 9 7 0}$ & $\mathbf{1 1 6 1 1}$ & $\mathbf{8 2 9 4}$ \\
\hline 2020 & $\mathbf{3 8 4 7}$ & $\mathbf{1 5 5 3 8}$ & $\mathbf{7 8 9}$ & $\mathbf{3 0 8 8}$ & 4636 \\
\hline
\end{tabular}

Forrás: Zenta Község Idegenforgalmi Szervezetének adatai alapján saját táblázat

A felsorolt adatok nem tartalmazzák azokat a látogatókat, akik egynapos kirándulás keretében látogatták meg Zenta községet.

6. ábra. A hazai és külföldi turistaérkezések száma 2015-2020 közötti időszakban Zenta Község Idegenforgalmi Szervezetének adatai alapján

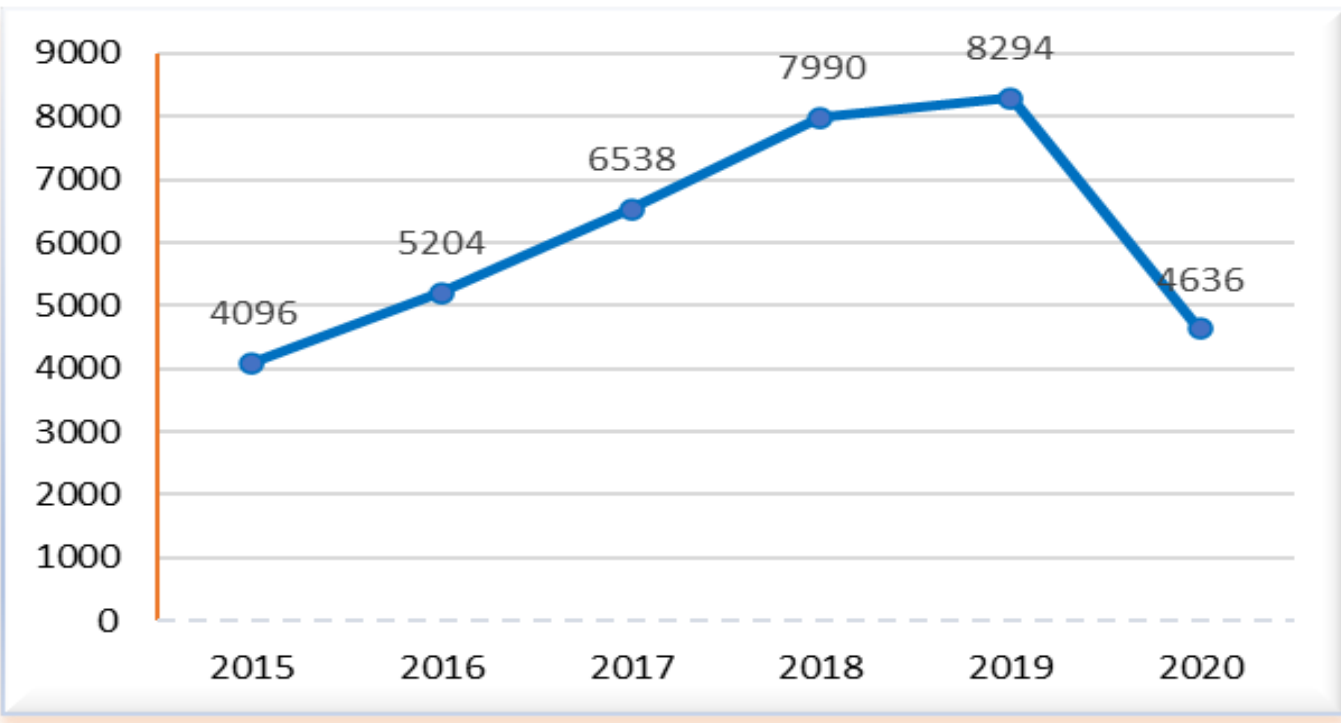

Forrás: Zenta Község Idegenforgalmi Szervezetének adatai aéaöküm saját ábra 
Az itt bemutatott adatokból kitünik, hogy lassú növekedés volt tapasztalható a Zentára látogató és a városban vendégéjszakát eltöltő turisták száma alapján 2015 és 2019 között, a növekedés mértéke 102,49\%-ban valósult meg, melyet a 2020-ban megjelenő koronavírus-járvány lassított.

\subsection{Város a zsebedben}

A jelenkorban a digitális, infokommunikációs alkalmazásoknak köszönhetően a turizmus iránt érdeklődők is otthonosabban mozoghatnak egy-egy településen vagy régióban. A Senta Info alkalmazás Zenta város történelmi, kulturális és turisztikai szempontból kiemelt jelentőségü látványosságainak a bemutatására jött létre 2019-ben, és hogy segítse a kisvárosba látogató turistákat a város megismerésében.

Az alkalmazás (https://play.google.com/store/apps/details?id=hu.jusoft.sentainfo\&hl=bs) leírja a város látnivalóit, segít megtalálni a nevezetesebb múemlékeket, templomokat, múzeumot stb. Elkalauzolja az érdekeltek a szálláshelyek, éttermek és programok keresésében.

\section{7. $\quad$ Összefoglalás és következtetések}

Egy közösség sajátosságát és megkülönböztető jegyeit a helyi kulturális, szellemi örökség teszi felismerhetővé. A Tisza mente régiójának földrajza és természetrajza aránylag hasonló jellemvonásokkal bír, a müvelődési sajátságok azonban minden községben eltérhetnek. Ez határozza meg a hely szellemiségét és különbözteti meg a községeket, településeket egymástól.

Interjúalanyaim mindannyian egyeznek azzal a megállapítással, hogy a Tisza mentén, így Zentán is igény mutatkozik a vidéki örökség átmentésére, és a lokális identitást erőteljesen befolyásolja és meghatározza az emlékezetben élö szellemi, kulturális örökség. A helyi közösségek célja, hogy a lehetőségek gazdagságát felismerve kortól, nemtől és anyagi helyzettől függetlenül minél többen aktív részesei lehessenek a helyi közösségi életnek. A kulturális, közmüvelődési termékkínálat és vidéki örökség oly módon integrálódjon az egyének mindennapi életébe, tevékenységébe, hogy azt a sajátjukénak érezzék, és maguk is hozzájáruljanak az értékmentéshez. A vidéki örökség, mint integráló erő, egy térség és az ott élő közösség kultúrája, valamint a történeti múltban élők halmozódó kulturális hagyatéka.

\section{Irodalomjegyzék}

BERGHAUER, S. - SASS, E. - TARPAI, J. - TÓTH, A. (2020): A helyi termékekben rejlő turisztikai erőforrások Kárpátalján. Turisztikai és Vidékfejlesztési Tanulmányok. 2020. október V. évfolyam III. szám, pp. 57-73. DOI: 10.15170/TVT.2020.05.03.04

CSURGÓ, B. - SZATMÁRI, A. (2014): Vidéki kultúra, helyi közösség és lokális identitás. A kulturális örökség szerepe a lokális identitásépítésben és a helyi közösségfejlesztésben Hajdúdorogon és Hajdúhadházon. Metszetek. 2014/3. 33-51. http://real.mtak.hu/18763/7/ 201403_03_csurgo_szatmari_0-1.pdf (A letöltés dátuma: 2019. 05. 04.)

KARANCSI, Z. - HORNYÁK, S. - SZALMA, E. - OLÁH, F. - KOROM, A. - HORVÁTH, G. - GYÖRI, F. (2020): A Tisza arcai, avagy a vízparti tájkép, mint turisztikai vonzerő - nem csak vízitúrázóknak. Turisztikai és Vidékfejlesztési Tanulmányok. 2020. június, V. évfolyam II. szám pp. 4-15. DOI:10.15170/TVT.2020.05.02.01

KÁRPÁTI, Á. - RIGÓ, R. (2019): Helyi identitás, helyi értékek gyüjtésének módszertana, a helyi identitástudat erősítés. In Tózsa István (szerk.): Hungarikumok és nemzeti értékvédelem. Dialóg Campus Könyvkiadó, Budapest, pp. 63-86. 
KEMÉNYFI, R. (2001): Az etnikai kisebbség (csoport) fogalmának eltérése az állam-és a kultúranemzeti elgondolásban. In: Illyés Zoltán - Keményfi Róbert (szerk.): A táj megértése felé. Debreceni Egyetem Néprajzi Tanszék, Eszterházy Károly Főiskola Földrajz Tanszék, DebrecenEger, 2001. pp. 205.

KOVÁCS, T. (2016): A Kárpát-medencei magyar kisebbségek nemzeti identitása és haza fogalma. Kisebbségkutatás (25) 4., 77-119.

PETI, L. (2009): A testvérfalu-kapcsolatok, mint a falusi turizmus és az identitásépítés színterei. In: Nemzetiségi - nemzeti - európai identitás. pp. 115-134.

POLYÁK, A. (szerk.) (2016): Az értékfeltáró tevékenységek helye a Nemzeti Művelődési Intézet szakmai munkájában. In: Értékekre hangolódva. A nemzeti értékgyüjtés módszertani kézikönyve. Budapest: Nemzeti Mủvelődési Intézet, pp. 25-35.

SEN, A. (2003). Társadalmi kirekesztés: Fogalom, alkalmazás és vizsgálat I. In CSURGÓ, B. LÉGMÁN, A. (2015): Lokális közösség, megtartó közösség. Elméleti megközelítések a lokális közösség integráló szerepének vizsgálatához egy vidéki településen. DOI: 10.18030/socio.hu.2015.4.50 www.real.mtak.hu (A letöltés dátuma: 2021. 04. 19.)

SIMOVIĆ-HIBER, I. - KARTAG-ÓDRI, Á. (1997): A kultúra és identitás (emberi) jogi aspektusai. Létünk. 1997. 3-4. 300. 293-307.

TŐZSÉR, A. (2019): A Délvidék/Vajdaság turisztikai kínálata és kereslete. Turisztikai és Vidékfejlesztési Tanulmányok. 2019. szeptember, IV. évfolyam III. szám. pp. 36-50. DOI: 10.33538/TVT.19.04.03.3

ÚJVÁRI, E. (2009): A kulturális identitás kérdésköre és kutatásának lehetséges irányai. A SZTE JGYPK Felnőttképzési Intézetének identitáskutató programja. In Szirmai Éva - Újvári Edit (szerk.): Nemzetiségi - Nemzeti - Európai identitás. Szeged http://mek.oszk.hu/08200/08200/08200.pdf (A letöltés dátuma: 2020. 10. 19.)

VÁZSONYI, CS. (2020): Értékeink tükrében. In: Klamár Zoltán (szerk).: Mi a magyar most, Vajdaságban? II. Néprajz-antropológia. Újvidék, 2020. pp. 341-348.

VERES Valér (2005): Nemzeti identitás Erdélyben - Szociológiai olvasatban. Akadémiai Kiadó, Budapest.

\section{Egyéb források}

A VAJDASÁGI MAGYAR KÖZÖSSÉGET ÉRINTÖ IDEGENFORGALOM FEJLESZTÉSI STRATÉGIÁJA (2018). Újvidék-Szabadka. www.prosperitati.rs (A letöltés dátuma: 2021 04. 21.)

IRÁNYELVEK. A LAKOSSÁG BEVONÁSA A KULTURÁLIS ÖRÖKSÉG
HASZNOSÍTÁSÁBA

INTERREG CENTRAL EUROPE, https://interreg-central.eu (A letöltés dátuma: 2021. 05. 04.)

LOVAS, I. (szerk.) (2011): Vajdasági Magyar Kulturális Stratégia 2012-2018. https://www.mnt.org.rs/sites/default/files/attachments/vajdasagi_magyar_kulturalis_strategia_201 2-2018.pdf (A letöltés dátuma: 2018. 05. 21.)

SZAKÁLI, I. L. (2019): Hungarikumok. In Tózsa István (szerk.): HUNGARIKUMOK és nemzeti értékvédelem. Dialóg Campus Könyvkiadó, Budapest. pp. 41-62. http://unipub.lib.unicorvinus.hu/4066/1/HUN_UJ_Ideig_TK.pdf (A letöltés dátuma: 2020. 05. 03.) 
SZERBIAI STATISZTIKAI HIVATAL (Republički zavod za statistiku) www.stat.gov.rs (A letöltés dátuma: 2021. 04. 15.)

SZÖKE, A (2015): Kitalált ünnepek, mint az önszerveződés formái. www.vmtt.org.rs(A letöltés dátuma: 2021. 04. 19.)

THURZÓ LAJOS MÜVELÖDÉSI-OKTATÁSI KÖZPONT http:/www.tlkk.org/varosi-konyvtar (A letöltés dátuma: 2020. 10. 24.)

ZENTA KÖZSÉG IDEGENFORGALMI SZERVEZETE www.sentainfo.org(A letöltés dátuma: 2020. 04. 14.)

ZENTAI MAGYAR KAMARASZÍNHÁZ http://www.zentaimagyarkamaraszinhaz.com(A letöltés dátuma: 2021. 03. 24.)

VAJDASÁGI MAGYAR ÉRTÉKTÁR, http://www.ertektar.rs(A letöltés dátuma: 2021. 05. 04.) 